\title{
Two new cotylean genera of Polyclads from Japan and remarks on some other Cotyleans.
} By

\section{SIXTEN BOCK, Uppsala.}

With 2 Plates and 6 Figures in the text.

Communicated November 9th 1921 by HJ. Théel and E. Lönnbera.

During my stay at the Biological Station at Sagami Bay, Misaki, in Japan, I met with two interesting turbellarians which, though genuine polyclads, closely resemble the triclads in their habitus. I failed at first to detect their true nature in the living specimen, as they were too opaque to trace their internal organisation.

Both species occur amongst Corallina in tide-pools or at the low-tide limit. They were taken in May and June 1914. They are among the smallest polyclads I have ever met with. Their power of contraction is very slight and they change the shape of their body extremely little. They seem to be very slow in their movements. Both genera also agree in having their dorsal surface pigmented, with an intense, brown pigment which makes it impossible to trace the internal stucture. Ventrally they are unpigmented. Both are of about the same size but their different marking makes it very ease to distinguish them.

Chromoplana bella n. g. n. sp.

This new species has its dorsal surface coloured in such a way that at a glance it is easily distinguishable from all other Polyclads (I, fig. 1). The dorsal surface is provided 
with four longitudinal bands of a fuscous blend. These bands are of such an extension and width that the uncoloured area is limited to a narrow marginal band, a notch-like spot at the anterior end, a field over the brain and three very longitudinal lines in the middle part of the body. The two middle symmetrical, brown longitudinal bands which begin close behind the brain are much narrower than the coloured side-fields.

The body is $3 \mathrm{~mm}$. long and $1 \frac{1}{3} \mathrm{~mm}$. broad. The animal is unusually thick in relation to its size, $2 / 3 \mathrm{~mm}$. The shape of the body is almost oval, slightly pointed at the

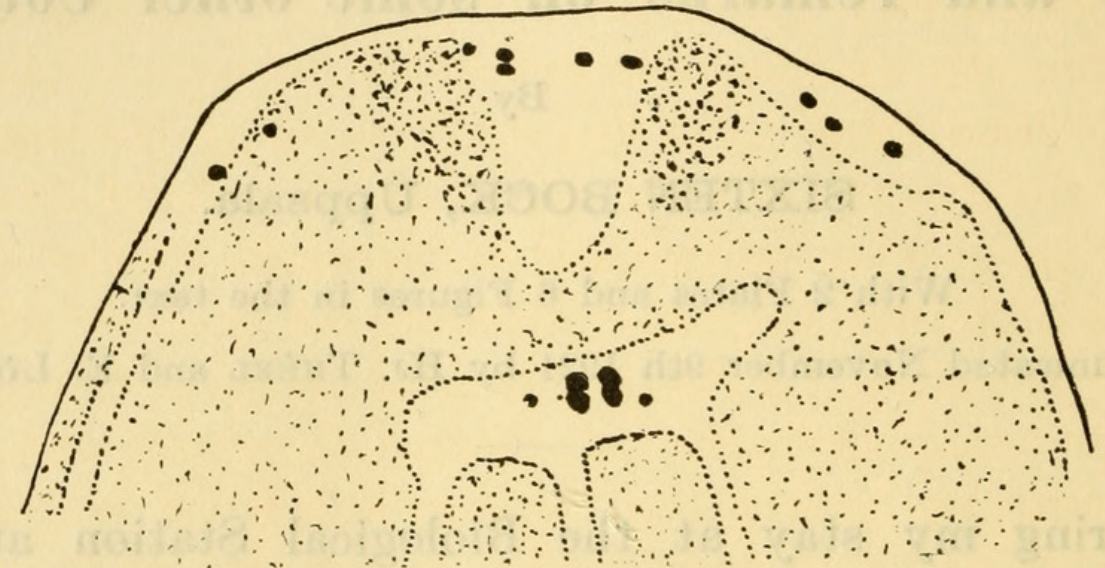

Fig. 1.

Chromoplana bella n. g. n. sp. Sagami Misaki 13th of June 1914. Zeiss Obj.A $\times$ Oc. 2. The frontal end of the body, seen from the dorsal side.

end. The anterior frontal line may be more or less straight. Marginal tentacles are totally absent.

It has not the thin and delicate body of other Polyclads and it is in this respect much like the marine Triclads, as pointed out above.

The arrangement of the eyes (text fig. 1) is characteristic, there being only three pairs of cerebral eyes and a very small number of marginal or, as I should rather like to call them, margo-tentacular eyes; in spite of that there are no traces of any tentacles at all. There can hardly be any doubt that they, as well as the similarly situated eyes in Aceros and Prostiostomum, correspond to the tentacular eyes of the Pseudoceridce and Euryleptidce. These marginal eyes occur in a single row at the frontal end and are hardly separated in two distinct clusters. This arrangement might therefore possibly indicate that the ancestors of Chromoplana have never possessed any tentacles. 
The two pairs of large cerebral eyes are situated close to the dorsal epithelium, just beneath the dorsal muscle layers of the body. They have their pigment cups directed so that the light falls into them from ahove. On the lateral side of each pair there is one much smaller eye. These two small eyes are very close to the brain and in that way situated beneath the layer of pigment above the brain which will be mentioned later on. On account of this position in the immediate vicinity of the brain, which as usual approaches the ventral side, the pigment cups are open on their ventral side. Thus the light can reach the sensible rods only from the ventral side and must then pass through the brain. These small eyes are innervated by the same nerves which run to the double pairs of large eyes. The two pairs of large eyes correspond to those in Stylostomum.

The external mouth is situated at the end of the first third of the body. It leads into a pharyngeal chamber which is rather comprehensive to belong to a cotylean polyclad, j. e. occupying nearly one third of the body length.

The relatively large sucker is at the end of the third quarter of the body.

The epithelium of the body is high and provided with dense but short cilia. In the dorsal epithelium there is the above-mentioned brown dense pigment which also occurs in the muscularis and parenchyma beneath the dorsal epithelium.

It is noteworthy that the long and slender rbabdites are numerous only on the dorsal side. On the ventral side another kind of acidophilous gland cells is abundant; these produce a granular secretion. Another interesting feature is the occurrence of nematocysts in the dorsal epithelium. Hitherto nematocysts have been met with amongst polyclads only in Stylochoplana tarda(by v. GrafF) and Anonymus virilis (by LANG, 1884). From this occurrence the conclusion can be safely drawn that this polyclad feeds on Cnidarians, probably Hydroids. These cnidarian capsules, already burst or undamaged, occur in the alimentary canals both in the lumen and in the intestinal epithelium cells as well as in the parenchyma of the body. As the basement membrane is rather thin they find no great difficulty in penetrating through it. Obviously these unburst capsules serve as de- 
fensive weapons for this polyclad. In accordance with that they occur almost exclusively on the dorsal and lateral parts of the body. There they can be seen with their intact stylets protruding out of the epithelium. A lot of empty capsules show that some of them also have functioned. Their great number indicates that they must be of value for the protection of the animal. In a single transverse section, $5 \mu$. thick, I counted more than fifty capsules. This will give a very considerable number for the whole animal.

Behind the frontal line there is, as always in the polyclads, an epithelial transverse sensory furrow and in connection with it there is an unusually large mass of subdermal mucuous glands which fill up the anterior end of the body. Beside this transverse furrow this polyclad possesses a peculiar and unique epithelial furrow (Plate II, fig. 1), running on each side in the length direction of the body but only in the anterior half of it. This furrow is strictly marginal, having rather a dorsal position on the very thick margin. As in the transverse furrow, the deepening of it is formed by the cells being much lower - less than half than the ordinary epithelial cells. The most characteristic feature of the furrow is the presence of epithelial mucous gland cells of a special kind. They are columnar, not saclike as such cyanophilous cells usually are. The secretion is stained more deeply than common mucous glands, resembling in this respect the glands of the frontal sensory organ of certain other turbellarians (some alloeocoels) and nemerteans. It is tempting to assume that these marginal furrows bave a sensorial function and the occurrence of these special gland cells makes it probable that this may be similar to that of the frontal organ and cephalic organs of the nemerteans, i. e: an organ of smell or rather a chemical sense organ. The gland cells occur in a row consisting of two cells in breadth on the ventral side of the furrow, guarding in this way the entrance to the furrow. The preservation was not good enough to allow more detailed researches on the sensorial cells.

The colour of the animal is caused by the presence of brown pigment granules in the dorsal epithelium and beneath it. As Chromoplana lives in tidal pools much exposed to the sun this dense and dark pigment must be of value 
as a protection against the rays of the sun. Accordingly when the cerebral eyes must be exposed to the light the pigment which has to protect the brain must be removed to the immediate neigbourhood of the brain, constituting an extensive and thick cover for this delicate organ. Such an arrangement of the pigment has not hitherto been observed for the polyclads.

The pigment granules are completely of the same kind in the epithelium and in the parenchyma. They are of varying size, $1 / 2-2 \mu$, and usually more or less elongate oval. The smallest, however, are spherical. In shape the large pigment granulae diverge from the granulae in the pigment cups of the eyes, which are always spherical. It is noteworthy that while the pigment granulae of the body vary much in size those of the eyes have the same size. Both kinds of granulae agree exactly in colour.

\section{Intestine.}

The external mouth is centrally placed in respect to the pharynx (text fig. 2). The pharyngeal sac is spacious, occupying more than one fourth of the bodylength and is situated in the anterior half of the body. It contains a much folded pharynx and agrees with the pharynx-type which LANG (1884) has named "krausenförmig". As the preservation of the pharynx is not good,

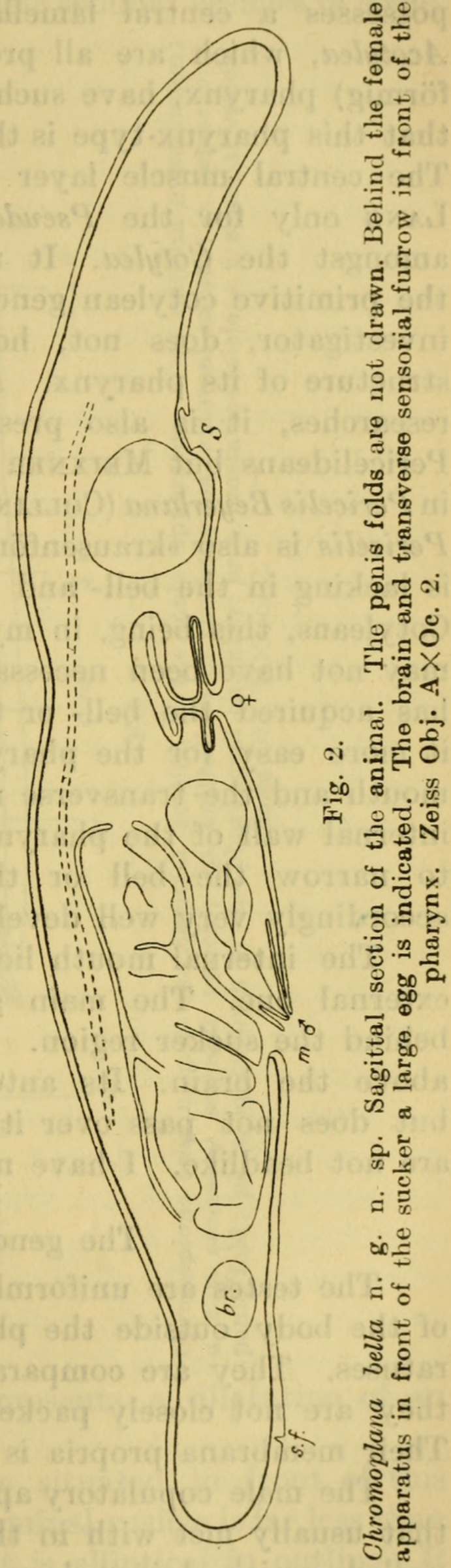


I may at present leave a detailed description of it out of this account, but I must point out that the pharyngeal fold possesses a central lamella of circular muscle fibres. The Acotylea, which are all provided with a orinkled (krausenförmig) pharynx, have such a central layer and I must think that this pharynx-type is the primitive one for the Polyclads. The central muscle layer in the pharynx is mentioned by LANG only for the Pseudoceridoe and the genus Eurylepta amongst the Cotylea. It may very probably also occur in the primitive cotylean genus Anonymus, but LANG, its only investigator, does not, however, mention the histological structure of its pharynx. As I can ascertain from my own researches, it is also present in the pharynx of some new Pericelideans but Meixner (1907, p. 475) failed to observe it in Pericelis Beyerlana (Collingwood) Laidlaw. The pharynx of Pericelis is also »krausenförmig". This central muscle lamella is lacking in the bell- and tube-shaped pharynx of the other Cotyleans, this being, in my opinion, a secondary feature. It may not have been necessary to keep it when the pharynx has acquired the bell- or tube-shape, as these shapes make it more easy for the pharynx to be protruded through the mouth and the transverse muscle layers of the external and internal wall of the pharyngeal fold being sufficiently strong to narrow the bell or the tube; these muscle layers are accordingly very well developed in these pharynx-types.

The internal mouth lies a little behind the level of the external one. The main gut is wide and can be followed behind the sucker region. There is no unpaired gut branch above the brain. Its anterior end just reaches the brain but does not pass over it. The gut branches are few and are not beadlike. I have not observed them to anastomose.

\section{The generative organs.}

The testes are uniformly distributed in the ventral zone of the body outside the pharynx and the copulatory apparatuses. They are comparatively large, 100-150 $\mu$, and, as they are not closely packed, their number is not excessive. Their membrana propria is well defined and thick.

The male copulatory apparatus (text fig. 3 ) is very unlike that usually met with in the Cotylea. There is a large thinwalled vesicle lying close below the pharyngeal sac and 
filled with a large mass of spermatozoa. This large reservoir, which is unpaired and situated in the median line, corresponds in function to the paired false seminal vesicles of some

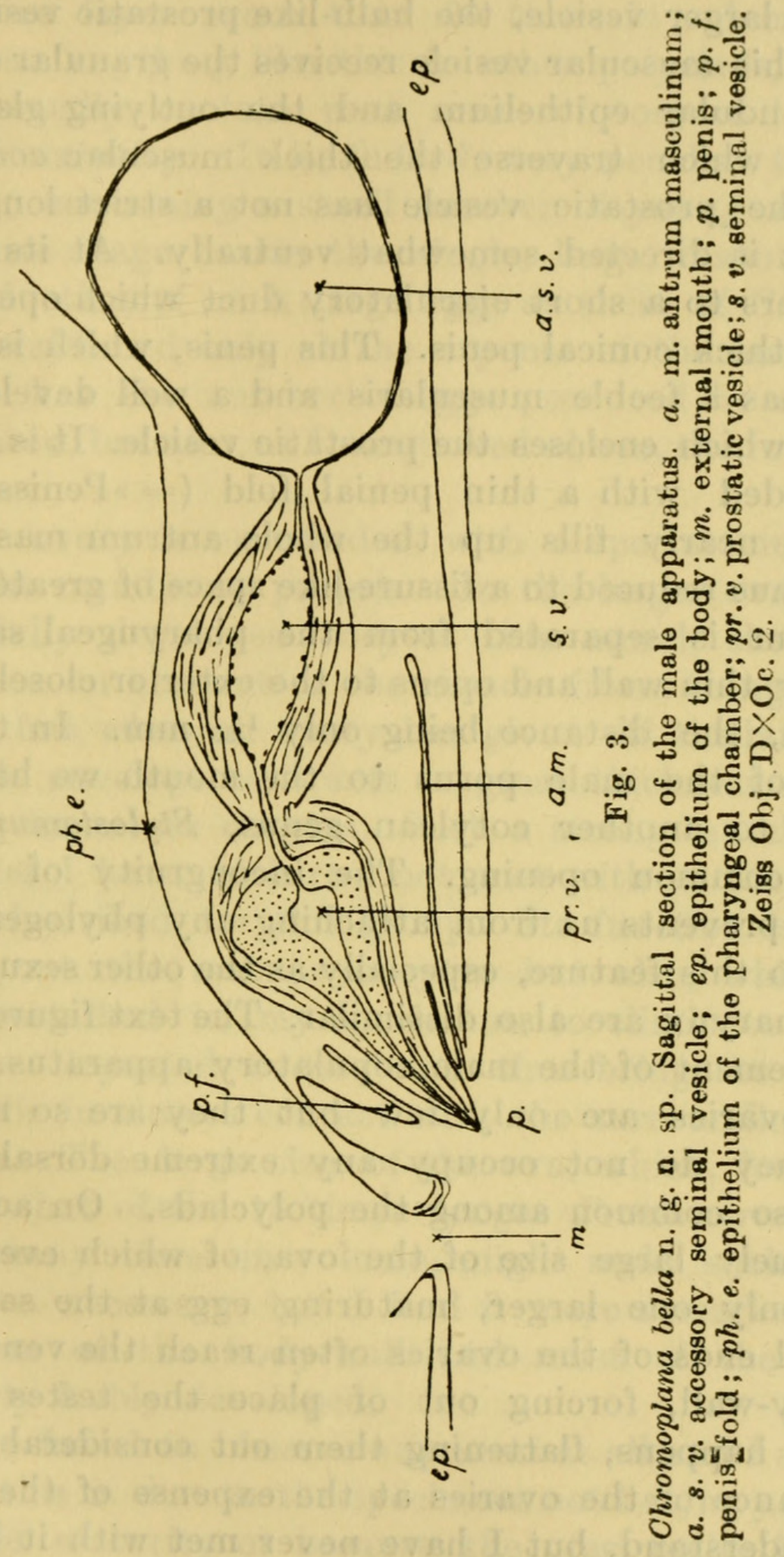

Acotylea. Morphologically it represents a dilatation of an unpaired vas deferens.

The true seminal vesicle is situated in front of this spermic reservoir. In size this seminal vesicle is far less than the spermic reservoir; in shape it is elliptical in outline. It 
is provided with a thick muscular sheath. The passage between the two sacs is very short. The true seminal vesicle in its turn opens by means of a short duct in the back end of another larger vesicle, the bulb-like prostatic vesicle. The lumen of this muscular vesicle receives the granular secretion of the glandular epithelium and the outlying glands, the ductuli of which traverse the thick muscular coat of the vesicle. The prostatic vesicle has not a strict longitudinal course but is directed somewhat ventrally. At its anterior end it tapers to a short ejaculatory duct which opens at the apex of a thick conical penis. This penis, which is directed forward, has a feeble muscularis and a well developed parenchyma which encloses the prostatic vesicle. It is unarmed and provided with a thin penial fold (=»Penisscheide»). The penis nearly fills up the whole antrum masculinum, which is thus reduced to a fissure-like space of greater length. The antrum is separated from the pharyngeal sac by an exceedingly thin wall and opens to the exterior closely behind the mouth, the distance being only $1 / 35 \mathrm{~mm}$. In this close approach of the male porus to the mouth we have a resemblance to another cotylean genus, Stylostomum, where there is a common opening. The incongruity of the male apparatus prevents us from attaching any phylogenetic importance to this feature, especially as the other sexual organs and the pharynx are also dissimilar. The text figure 3 shows the arrangement of the male copulatory apparatus.

The ovaries are only few but they are so much the larger. They do not occupy any extreme dorsal position which is so common among the polyclads. On account of the extremely large size of the ova, of which every ovary contains only one larger, maturing egg at the same time, the ventral ends of the ovaries often reach the ventral muscular body-wall, forcing out of place the testes or, as it sometimes happens, flattening them out considerably. This preponderance of the ovaries at the expense of the testes is easy to understand, but I have never met with it before in the polyclads, where the male and female reproductive organs are usually restricted to different regions of the body.

The germinative zone of each ovary is variably placed: dorsally, ventrally and laterally, and contains only a few small cells. The largest of these young ovarial cells of the 
germinative zone reaches only $30 \mu$, while in the same ovary the single large maturing oocyte can be more than $1 / 4 \mathrm{~mm}$. in diameter. Thus the latter oocyte surpasses the whole germinative layer more than 20 times in volume. I have never seen anything like this in other polyclads, where the ovaries usually contain neat series of oocytes in different stages of maturity. It is, indeed, very peculiar to see such an ovary, containing a small number of young ovarial cells of the same stage beside the single, large, maturing »egg». The production of such large eggs as these of Chromoplana can be established only at the expense of the number. But not only has the number of eggs produced by each ovary been reduced, but also, as I mentioned above, the total number of ovaries.

Each ovary is surrounded with a special muscle cover outside the membrana propria. In the larger ovaries which contain fully developed oocytes this muscle sheath is less conspicuous on account of the muscle fibres being extremely extended, but when an ovary has given off the large oocyte, the muscle envelope contracts to great thickness around the remaining immature oocytes. Such a strong muscle cover of the ovaries I have hitherto not met with in the polyclads nor is it described for this group. Its function is not only to drive out the mature oocytes but also, which can be easily ascertained in my specimens, to eliminate the space left by the departed oocyte and thus bring the remaining ovarial cells in closest contact with the surrounding nourishing tissue. The large size of the ova, which, for instance, surpasses that of the 15 times longer Prosthecercus vittatus (MONT.) many times in volume, might make such a strong museulation necessary, but $I$ find it more remarkable as the musculation of the body-wall and most of the organs is particularly feebly developed.

I have failed to observe any uteri at all and I am unable to say if this is due to the specimens not having yet reached full female maturity or because the uteri really have been reduced. I am inclined to take the latter view as the ovaries generally contain eggs which have attained full maturity and are ready for impregnation and deposit. If this reduction of the uteri actually has taken place, and there is much in 
favour of this, the conclusion is obvious that it is caused by the largeness and fewness of the ova.

The female apparatus in the median line is not very far away from the male apparatus, as may be gathered from the text figure 2. It is not very long, running first straight horisontally forward, then bending in a sharp curve ventrally, to be expanded in a horisontally placed fissure-like shellchamber of the type which is so characteristic of the cotylean polyclads, and then passing in a vertical course to open to the exterior. The hinder part of the apparatus is lined with high epithelial cells containing a thread-like secretion. On account of the large eggs the flat and round shell-chamber has a large diameter, larger than is usual in the Cotyleans in spite of the small size of the body. It must be considerably spacious when expanded. In the chamber I have observed masses of shell secretion, the granula having melted together to form homogeneous bodies.

The shell glands are of a peculiar type, the bodies of the cells being nearly spherical, and the secretion granula are also round, not, as usual, rod-like.

Systematic position of the genus Chromoplana.

With our present knowledge of the cotylean polyclads it is rather difficult to make out the relationship of this new genus and it is necessary to treat this subject in considerable detail. In his excellent monograph on the polyclads LaNG arranged the cotyleans in four families.

1. Anonymida, with a single, but very interesting genus containing but one species, has a thin oval body lacking tentacles. The pharynx is very much folded and situated in the middle of the animal. There are numerous male copulatory organs situated exclusively(?) in the lateral fields of the body. The female apparatus is not described by Lang. Eyes occur marginally around the body and in two cerebral clusters. The gut-branches anastomose frequently. The microscopic weapons mentioned by LANG in the diagnosis have no systematic value at all as they are nematocysts of Cnidarians introduced in the body together with the food. This genus has a very isolated position.

2. The two families Pseudoceridoe and Euryleptidoe can 
in this exposé be taken together as they are undoubtedly closely akin. They contain the greatest number of cotylean genera with the main part of the species. The body is more or less ovate and usually with two marginal tentacles. The tentacles may sometimes be reduced (Stylostomum) or lost (Aceros), the tentacle eyes still indicating them and their place. We see how the pharynx is still folded in the Pseudoceridoe but in a less excessive degree and acquires a bell shape in the Euryleptidoe. The male copulatory apparatus has in these two families a conformity unknown elsewhere among the turbellarians. That it may be double in some species of the Pseudocerido is of no great systematic importance, the structure of the apparatuses being quite of the typical aspect. The penis is always (when single) directed forward and is armed with a stylet and provided with penis-folds. The prostatic vesicle is independent and opens together with the seminal vesicle situated usually posteriorly, at the base of the penis. The female organs show variability in the oviducts, uteri, accessory vesicles, but the median »copulatory" apparatus (the short vagina seems here to be used only or chiefly for the deposit of the eggs, the sperma being as a rule injected in the tissues of the body without regard to the place) is exactly of the same, very simple type. An interesting feature is that it is always provided with a transverse dilated shell chamber.

3. The Prosthiostomidce form the third of the cotylean types known to LaNa 1884. They have an elongated body and lack tentacles. The pharynx is tubular and the mouth is close behind the brain. The main gut is very long, provided with numerous non-anastomosing gut-branches. The male apparatus is of a type unique in the turbellarians: a short penis armed with a hook-like stylet and two strongly musculated accessory vesicles; the granular glands are in the penis fold. The seminal vesicle lies behind the penis. The female median apparatus conforms to the type previously mentioned.

It is obvious that when considering the systematic position of Chromoplana the first and third of these types must be left out of account. With this second series, forming the heavy centre of the cotyleans, there is agreement in some respects but not sufficiently great to include the 
new genus in any of the two families. In the exterior features we have resemblances in the outline of the body, in the position and structure of the sucker, in the position of the genital openings. With some Euryleptidoe the absence of marginal tentacles is a common feature. But one must bear in mind that this characteristic is a negative one and therefore too much importance is not to be attached to it. 'The arrangement of the eyes is nearly of the same type, there being marginal eyes at the frontal line as in Aceros, an Euryleptid genus, and the cerebral eyes form two clusters (not so well marked, it is true, as they are few both in Chromoplana and Aceros) as in all the Cotyleans. It is certainly interesting to find that the two pairs of large eyes above the brain, so characteristic of Stylostomum and Aceros, are also present here in Chromoplana. This must be an ancestral feature in the two Euryleptid genera mentioned as well as in Chromoplana, as we also find a similar arrangement in MüLleR's larva of the Pseudoceridoe (as examples I may refer to LANG's figures, 1884, Taf. 39, figs. 10 and 13 of the larva of Yungia and Thysanozoon). Very young forms of Thysanozoon have an arrangement of the eyes like that of Aceros (compare LANG's Text figure 50 for Aceros with Taf. 39, Fig. 13 for Thysanozoon). As further evidence for the ancestry of this feature, it may be mentioned that very young specimens of the Prosthiostomidoe also show a similar arrangement (LANG, 1884, Text fig. $51 \mathrm{~A}$ ), which one would hardly expect from the appearance of the cerebral clusters of the full-grown specimens.

It is, indeed, of great interest to find how such features as the position, number and relative size of the eyes, which at first one would not lay much stress on in settling systematic relationships, are retained with greatest tenacity in the larval development in the three different families Pseudocerido, Euryleptidoe and Prosthiostomida. This cotylean larval arrangement of the eyes, which is met with previously in the full-grown specimens of only one cotylean species, Aceros inconspicuus LANG from the Mediterranean Sea, is still kept in the sexually mature specimens of this new genus from the Pacific. It may be considered an ancestral feature.

The coloration of Chromoplana is caused by real pigment 
SIXTEN BOCK, TWO NEW COTYL. GEN. OF POLYCLADS. 13

in the epithelium and beneath the basement membrane just as is the case in the Pseudoceridoe and Euryleptidae as well.

The pharynx of Chromoplana agrees with that of the Pseudoceridoe, but not with that of the Euryleptidoe. The pharyngeal chamber of the former family is usually unbranched, in Chromoplana it is provided with some side pockets.

The intestine of Chromoplana is, on the other hand, more similar to that of the Euryleptidoe, the gut-branches freely anastomosing in the Pseudoceridce. But this seems to be of no very great systematic value, to judge from the conditions of other genera of polyclads.

The female terminal apparatus agrees well with the common cotylean type, and so with both the families mentioned. The absence of the uteri is probably a secondary, not a primitive feature, if it really is a usual feature in the genus. On the other hand nothing can be said about the absence of the accessory vesicles which generally occur in the Pseudocerids and the Euryleptids.

The male copulatory apparatus of Chromoplana is differently organized from that of other Cotyleans yet described. It is more like that which we meet in the acotylean family Leptoplanidae or even still more like that of the Cestoplanidoe, where the male apparatus is directed forward, the only exception to the rule in the Acotyleans. Of all the Acotyleans the Cestoplanidce are most closely related to the Cotyleans. The male apparatus of the Pseudoceridoe and the Euryleptidae are of such uniform shape and structure that different genera cannot be distinguished by it. There is in this new genus a large reservoir for sperma behind the true seminal vesicle. The sperma must on its way out pass through the prostatic vesicle, as the seminal vesicle opens in the back end of the prostatic vesicle, the first example known in the Cotyleans. In shape and direction as well as because it is provided with a penis-fold the penis is like that of the two families referred to. But the penis is unarmed here, while it is, without a single exception, armed with a stylet in those families. That is, however, of no great importance, as we can judge fromt he conditions in the Leptoplanidoe. The genera Stylochoides, Enterogonimus, Leptoteredra and Laidlawia in the Cotyleans point in the same direction but to a less degree, 
as they also deviate in other respects from the Euryleptida, their nearest relatives.

From this discussion the conclusion can be drawn that Chromoplana is certainly in some way related to the Pseudocerid-Euryleptidean series but the differences in the male apparatus are so big that they do not allow us to include it in either of these families, all the more as just with regard to the generative organs the Pseudoceridoe and Euryleptidce show the greatest conformity.

It still remains to adopt a view concerning the Cotyleans described since LaNG's monograph was published. Most of them have without any difficulties at all been properly included in LANG's families. Only the following genera need any further discussion: Pericelis (LAIDLaw, 1902 and MeIXner 1907), Diposthus (Woopworth, 1898) and the four genera Stylochoides (HALLEz, 1907; see also Bock, 1913, pag 276), Laidlawia (HERZIG 1905 and $\mathrm{Z}_{\mathrm{AHONY}}$ 1907), Enterogonimus HALLEZ 1911 (HALLEZ, 1913) and Leptoteredra (HALLEZ, 1913), by HALLEZ 1913 included in his sub-family Laidlawiince under the family Euryleptidae.

I find it necessary to treat HALLEz's genera at some length, as my views may be of some value for future investigators of the antarctic or subantarctic polyclad fauna to which they all belong, or at least to call attention to certain facts.

In 1905 HaLLEZ described an Aceros maculatus n. sp. from the Antarctic. This species is again treated by him in 1907, where a more detailed account is given. In a new memoir on the antarctic polyclads (1913) he established a special genus for it, Leptoteredra. There he also corrects some mistakes made in his previous anatomical description. He had stated (1907, p. 12) that 》l'appareil copulateur mâle ne mérite aucune mention spéciale. Par ses connexions comme par sa structure, il est conforme à celui de l'espèce méditerranéenne». According to LANG the Mediterranean Aceros inconspicuus possesses a penis stylet. Lang does not express this plainly, but in the first place he says that the male copulatory organ agrees with that of Stylostomum and secondly a stylet of this type can be traced in a schematic figure. In 1913 HALLEZ mentions that his species in question has a ppénis sans stylet». What Hallez in 1907 describes as eleven »vésicules utérines» is nothing else, as he himself 
points out $(1913$, p. 39$)$ but the ovaries. I have related this because HALLEZ's correcting remarks make it very probable that Aceros stylostomoides, described in August 1907 by J. F. Gemmill and R. T. Leiper, from South Orkney Islands is identical with Leptoteredra (Aceros) maculata (HALLEZ 1905) HaLLez 1913 [which was described anatomically first in July 1907] from Graham Land. Both were obtained at about the same depth, 9-10 fms. and 20 metres respectively.

Like Leptoteredra maculata the Aceros stylostomoides has a length of $3-4 \mathrm{~mm}$. and lacks tentacles. The position of the openings agrees well in both. The number of cerebral eyes is in A. stylostomoides $2 \times 15$, in maculata $2 \times 14-15$; tentacular eyes $2 \times 8-9$ and $11--12$ respectively on the ventral side. The pharynx is in both short and tubular. The main gut of both is spacious with five pairs of ramifying unanastomosing gut-branches and is as an exceptional feature provided with a dorsal porus. The genital organs of stylostomoides also agree well with those of Leptoteredra: The penis is large, of an elongated, pyriform shape, and bas no stylet. The last point is not expressly stated by the British authors, but can be seen in the figures given by them (1. c., Plate, fig. 1). There are in stylostomoides »two uteri into which the oviducts open. No uterine glands. The ovaries are found throughout the lateral parts of the body». Nothing is said about the number of the ovaries. But the following sentences bear an indication that a similar condition prevails in the specimens of the British authors as HALLEZ describes as the double function of the ovaries. Gemmill and Leiper write: "Many of the ovarian tubes contain yolklike material which seems to be derived from the transformation of cellular elements within their walls. This arrangement seems to replace the special uterine glands described as occurring in Aceros inconspicuus and certain other Euryleptidce».

The only differences I am able to make out from comparing the schematic figures given is that stylostomoides has the unpaired anterior gut-branch passing the brain while in maculata it does not reach the brain, and that in the former the sucker is large and in the latter it is rather small. In the description of $A$. stylostomoides we read further that the specimens 》are of a warm brown tint, mottled on the dorsal surface by a coarse, darkly pigmented network, the strands 
of which arise from a longitudnal band on either side of the middle line». Leptoteredra has the dorsal surface »toute maculée de taches pigmentaires d'un jaune rougeâtre, excepté sur ses bords et dans la région pharyngienne». It ought to be recalled that both descriptions are made from preserved specimens.

Whether these differences have such a value that we must distinguish between the specimens from Orkney Islands and Graham Land as different species is not easy to make out from the descriptions alone. It must be deplored that no habitus figures are given for A. stylostomoides. Anyhow it is certain that they belong to the same genus, Leptoteredra, and future investigations will perhaps reveal that there is only one antarctic species in that genus.

In speaking of Leptoteredra, interpreted at first as an Aceros, I will make reference to another polyclad which I think has been wrongly included in that genus. In a paper published by H. Heath and E. A. McGregor (1912) an Aceros langi $\mathrm{n}$. sp. is described, in which no prostatic vesicle was distinguished. If such a vesicle really is lacking it is impossible to regard that species as an Aceros. No »uterus glands» (uterine vesicles) could be detected. It is not mentioned that the penis is armed and the schematic figure is too poor to allow of a statement in that respect. Further, it is quite uncertain if marginal tentacles are absent or not. The great number of cerebral eyes at least do not speak in favour for the interpretation of it as an Aceros. As the sexual organs do not agree with the type of the Pseudocerida and the Euryleptidoe and as these organs are insufficiently known, no sections having been studied, it is impossible to discuss its relationship, all the more so as the anterior end of the animal was also damaged. It must at present be excluded from the genus Aceros.

Curiously enough, HaLLeZ in his later memoir (1913) knows nothing of the paper of the Scottish National Antarctic Expedition treating Antarctic polyclads, published already in 1907. As I have pointed out (Bock, 1913) Nuchenceros orcadensis GemmiLL \& LEIPER is identical with Stylochoi- 
SIXTEN BOCK, TWO NEW COTYL. GEN. OF POLYCLADS. 17

des albus HALLEZ, which HALLEZ consequently fails to observe when treatening Stylochoides very exhaustively.

In this connection I may add some remarks to Hallez's table (Hallez 1913, p. 41) for the five genera Stylochoides, Cotylocera, Laidlawia, Enterogonimus and Leptoteredra. HALLEZ states here that Laidlawia has $\gg 7$ paires de branches intestinales» whilst Enterogonimus possesses 13. But Rudolf von RitTer-ZAHONy says about the former $(1907$, p. 10) that $》$ der Hauptdarm gibt sieben breite, paarige Seitenäste und einen unpaaren vorderen Ast ab». Enterogonimus according to Hallez 1913, »presente treize paires de branches dont trois se trouves en avant du pharynx, sept entre le pharynx et la partie posterieuse de la ventouse, et trois en arrière de la ventouse». The first three pairs belong with certainity to the unpaired anterior gut-branch and I think that only the seven following pairs »entre le pharynx et la partie posterieuse de la ventouse» correspond to what $Z_{A H O N Y}$ calls the seven pairs of broad gut-branches of Laidlawia. In reality there is no difference in the number of large paired gutbranches from the main gut between Laidlawia and Enterogonimus.

The difference which HaLlez finds between the number of paired gut-branches of his Stylochoides albus and ZAHONYs Cotylocera michoelseni must, I think, be attributed just to the different way of counting these pairs. ZAHONY only counted the branches leaving the broad main gut (Hauptdarm) while HALLEZ counted all the branches diverging from the median intestinal canal, including the so-called anterior unpaired gutbranch. If then we read HaLLez's table (HALLEz 1913, p. 41) for Stylochoides and Cotylocera with common sense we shall find that the differences between these genera in reality do not exist or at least the table has no value at all in separating them. Thus we shall see in HaLlez's table how the two genera agree in having two tentacles (but it is not mentioned that these tentacles in both cases are nuchal which is, indeed, of considerable interest, as no other cotylean polyclad possesses such tentacles, they being otherwise marginal) further 》ventouse puissante», "gaine pharyngienne très longue», "pas de vésicule séminale».

According to the table they disagree in the number of gut-branches, which can be attributed to the different way

Arkiv för zoologi. Bd 14 . N:o 13. 
of counting them (compare what is said above). The distinction "pas d'uterus» for Stylochoides and 》2 uterus» for Cotylocera is not a difference in reality because what HALLEz calls »deux oviductes ventraux» (»qui se reunissent en un oviduct commun» (= Eiergang) corresponds to what Zahony describes as two uteri. ZAHONy says (p. 5): "Der relative weite Eiergang führt nach seiner Gabelung in zwei sackförmige, prall mit Eiern gefüllte Uteri, die ventral zuseiten der Pharyngealtasche liegen». The position of these is the same, to judge from the figures which Hallez and ZaHONY give, but the so-called »oviductes ventraux»(!) are narrow, because they do not contain any eggs.

In the table Hallez says, further, that Stylochoides has »23 ovaires» and Cotylocera »ovaires peu nombreux». First, I cannot believe that a certain number and such a figure as $23(!)$, is constant for the species, secondly ZAHONY says 》die Ovarien sind nicht sehr zahlreich".

The last note in HALLEz's table that Cotylocera has one "vésicule des glandes granuleux» and Stylochoides possesses one »vésicule accessoire» should really indicate a difference between these two genera, but as I have pointed out elsewhere $(1913,1$. c.) it is very probable that a mistake in this respect occurs in ZAHONY's description. It may be mentioned that I have a true Stylochoides from the same district in which ZAHONY's specimen was taken. Consequently I have in 1913 identified Stylochoides albus, Cotylocera Michaelseni and Nuchenceros orcadensis as the same species. The discussion of the above-mentioned table shows that Hallez's examination has not been sufficiently critical.

It remains now to compare Chromoplana with these genera which HALLEz includes in this sub-family Laidlawiince. As the male copulatory apparatus in those genera is very unlike that of Chromoplana and all the more as the pharynx is tubular I think that at present we have no sufficient reason for joining Chromoplana with them. The common features which can be found do not prove any very close relationship, as they might have been acquired independently: - The shape and size of the body, the absence of marginal tentacles (the Prostiostomidoe also lack tentacles), the few non-anastomosing gut-branches, the large size of the ovaries and the consequent small number of them. 
The genus Diposthus with the single species $D$. corallicola is described by WOODWORTH (1898). The peculiarities of its male sexual organs have necessitated Woodworth to establish a new family, Diposthiida, for the reception of this genus. The penis and prostate gland are separated sinto two distinct organs, both of which are doubtless intromittent». There are two large vesiculae seminales, the ducts of which unite to form the ductus ejaculatorius. The female apparatus possesses uterine vesicles which communicate with a common duct, the ducts of opposite sides uniting to enter the female atrium, which functions as a bursa copulatrix. Of the pharynx it is only said that $\gg$ it can be seen as a lighter ragged median streak». To judge from the figure (1. c., Plate, fig. 6) it is situated in the centre of the body and must be of the folded type; it probably has the pharyngeal chamber provided with side pockets. There are also $\gg$ two pointed conical tentacles close to the anterior margin».

The organisation of the male apparatus and the pharynx separates Diposthus from the Pseudocerida-Euryleptidce. The female organisation agrees well with the Pericelider, as does very probably the pharynx (and perhaps the tentacles). As both the male and female organisation, besides other features, are unlike that of Chromoplana we have no reason to unite these two genera in the same family.

The genus Pericelis, constituting its own family (see Laidlaw 1902 and Meixner 1907), still remains to be discussed. The single species has a very large, thin and excessively folded body with two marginal tentacles. Besides the cerebral eyes in two clusters, there are frontal eyes and a complete series of marginal eyes around the whole body. The pharynx is situated centrally and much crinkled ( $(\mathrm{krau}-$ senförmig»). The intestine is richly branched with anastomoses between the branches. The male apparatus has a backward directed fleshy unarmed penis without penis-folds. Meixner says: "Eine besondere, deutlich abgesetzte Körnerdrüsenblase fehlt Pericelis Beyerlana gänzlich, desgleichen konnte ich extrakapsuläre, im Mesenchym ausserhalb der Muskulatur gelegene Körnerdrüsen nicht entdecken». The ductus ejaculatorius can, according to MEIXNER, be divided into a proximal »vesicula seminalis», a middle prostatic part with granular gland cells in the epithelium, and a distal part, 
ductus ejaculatorius (in the proper sense). The female terminal apparatus is built according to the common cotylean type. The two longitudinal narrow uteri are provided with numerous uterine vesicles. The ovaries are very numerous and situated dorsally.

As can be gathered from this account there are too many divergencies to permit us to include Chromoplana in the Pericelidas. It is true that an allied form to Chromoplana, Amyella, described in this paper, shows certain similarities in respect to the male apparatus with Pericelis, such as a fleshy, unarmed penis without penis folds, no distinct prostatic vesicle, but too many divergencies are still left. Even the similar features mentioned must not be pressed too far, as with regard to the structure many discrepancies can be enumerated. And the direction of the male copulatory apparatus is opposed in the two cases.

I have all the more reason not to alter the family Pericelidoe as I have from the Pacific another cotylean genus with two species which I can include in this family, which still remains a typical tropical family.

As a result of this discussion it is evident that we cannot include Chromoplana in any of the hitherto established families. There are certain agreements in organisation with the Pericelidce, Pseudoceridoc-Euryleptidoe and Laidlawiidoe. I must therefore establish a new family, Chromoplanidoe, the diagnosis of which is given at the end of this paper.

\section{Amyella lineata, n. g. n. sp.}

Several specimens of this new polyclad were found in May and June 1914 at the Biological Station at Misaki. I collected them in the same locality where I found Chromoplana, i. e. among Corallina-weeds in shallow water and tidal pools close to the station.

It is a more narrow polyclad than Chromoplana, broad at the front, pointed at the end of the body. Its size is even smaller than that of the former genus, $2,8 \mathrm{~mm}$. in length, and $0,8 \mathrm{~mm}$. in breadth. Another specimen measured only $2 \mathrm{~mm}$. in length. It is the most minute polyclad ever described. In relation to its size it is very thick, $1 / 4 \mathrm{~mm}$. 
The dorsal side is furnished with six longitudinal bands, made up of a brown pigment but of a lighter shade than that of Chromoplana. These bands are at the frontal end joined into a broad pigmented area close to the frontal line, which area is of a darker shade than the separate bands. At the back end the bands run together and fuse. Plate 1, fig. 2 .

Tentacles are lacking.

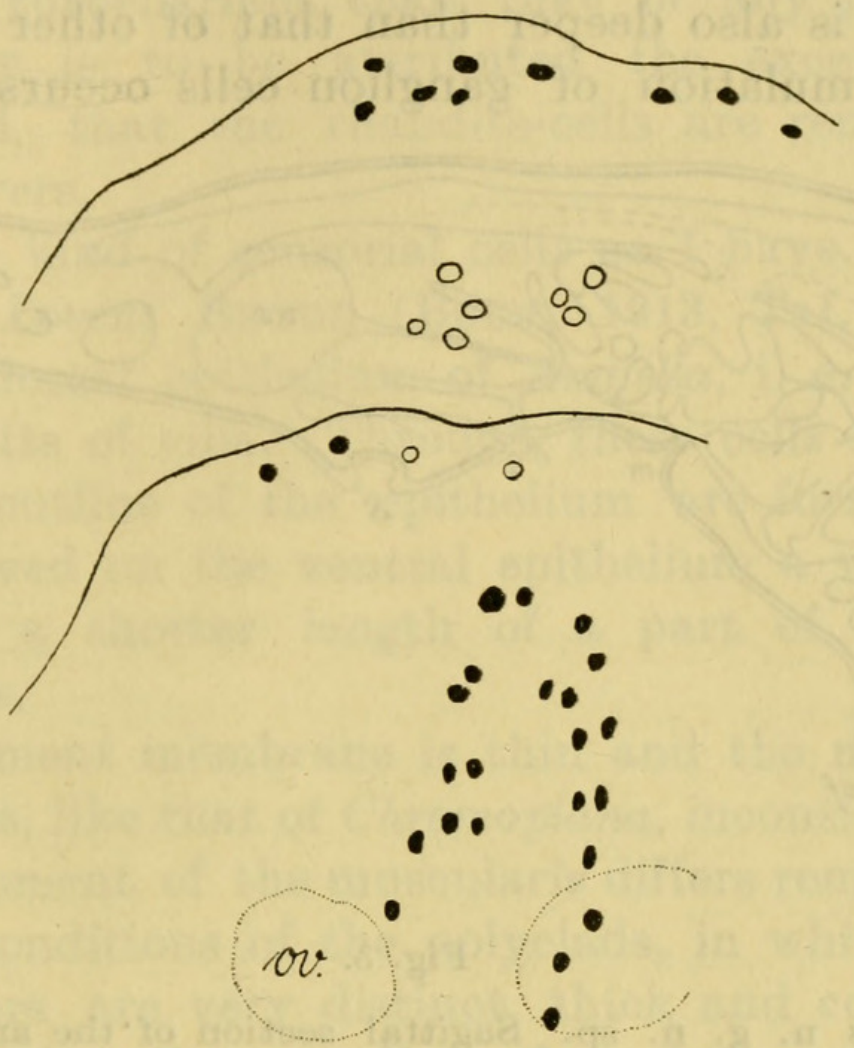

Fig. 4.

Amyella lineata n. g. n. sp. Above is shown the arrangement of the eyes on the ventral side. The foremost of the cerebral eyes are drawn. Beneath are the cerebral clusters seen from the dorsal side. All marginal eyes cannot be traced on account of the thickness of the body and the pigment ov. ovary.

There is a double cluster of cerebral eyes. Each cluster is elongated and formed by 10 to 12 eyes (text fig. 4). There are also marginal eyes on a restricted area just at the front of the animal. They occur in one or two rows, most of them visible only from the ventral side (text fig. 4, above). These marginal eyes form two not very distinct clusters, each made up of 3-6 eyes. It may be mentioned that the marginal eyes are only inconsiderably smaller than the cerebral eyes. In the position of the eyes there is nothing remarkable, agreeing fairly well with the arrangement generally met with 
in those Euryleptidoe which lack marginal tentacles or in the Prosthiostomidoe. The marginal eyes may then correspond to the tentacular eyes of the former family.

It is noteworthy that all the eyes, both the cerebral and the marginal ones, are situated very close to the basement membrane, the muscular layers being very thin.

There is a ventral, transverse, sensorial furrow situated closer to the brain than I have seen in any other polyclad. This furrow is also deeper than that of other polyclads. A special accumulation of ganglion cells occurs at the inside

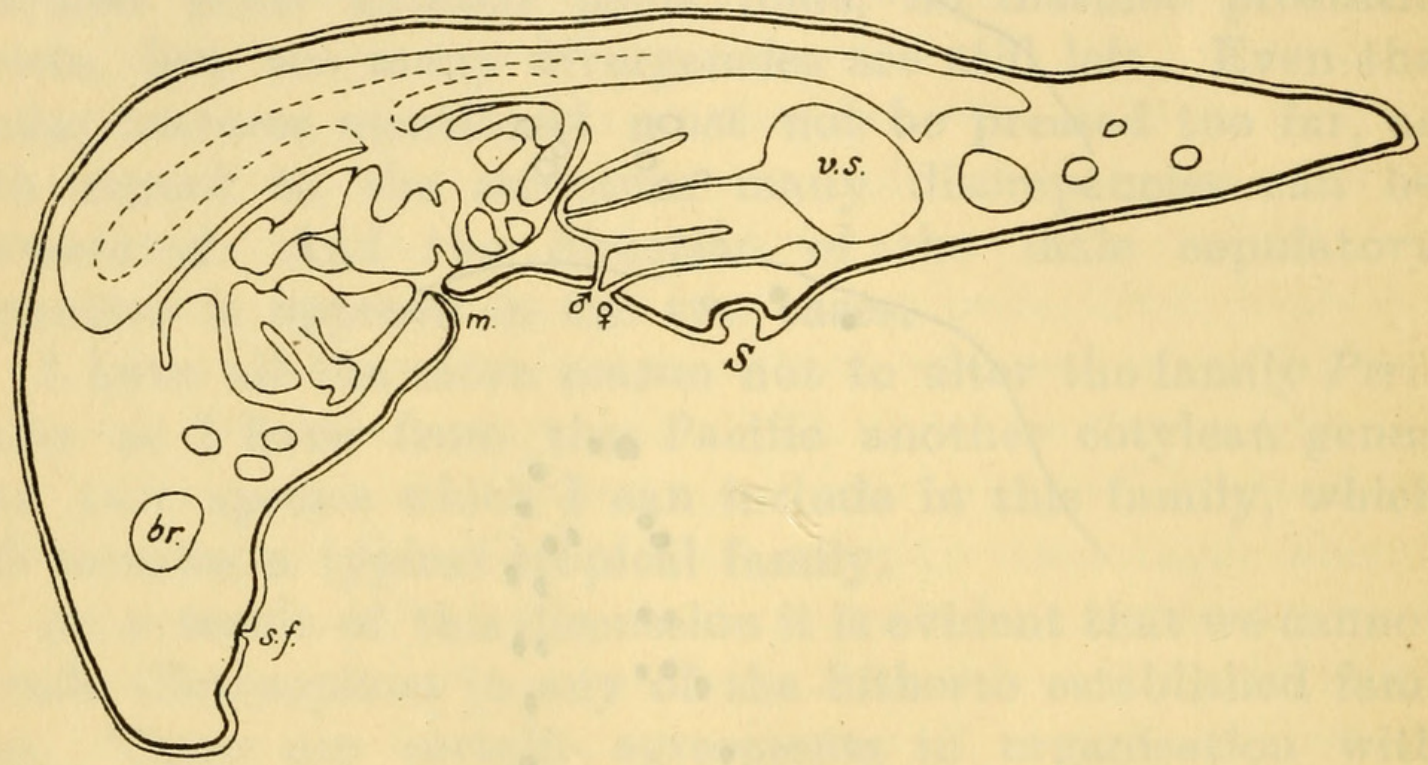

Fig. 5.

Amyella lineata n. g. n. sp. Sagittal section of the animal. The small circles behind the brain and the sexual apparatuses represent young ovaries.

The same enlargement as in text fig. 2, Zeiss Obj. A XOc. 2.

of the muscular wall for the innervation of this organ. The paired nerves connecting this assemblage of nerve-cells with the brain must be very short on account of the close position of the furrow to the brain; they are also very thick.

The mouth is to be found in the anterior part of the second third of the body. It occurs in the middle of the pharyngeal area, and as the pharyngeal chamber has a considerable size it is thus removed far from the anterior end.

The sexual pores are placed very close to one another and about halfway between the mouth and the sucker. On account of the large size of the male copulatory organ in relation to the small size of the animal the sucker thus lies below the back end of the male apparatus. 
Anatomical description.

Body-wall. The external epithelium is rather low for a polyclad, $10 \mu$ or less, and consists of very broad cells which gives it an unusual appearance for a polyclad. The nuclei are, in accordance with the shape of the cells, spherical and comparatively large $(4 \mu)$. Epithelial gland cells are extremely few. The epithelium is thus more like that of the alloeocoelean turbellarians than that of any polyclad. To this similarity is to be attributed the exceptional fact, for a polyclad, that the rhabdite-cells are removed to the subdermal layers.

The same kind of sensorial cells as I have described for Cryptocelides Loveni BRGDL (Bock, 1913, Taf. VI, Fig. 17) oceur in the dorsal epithelium of Amyella, i. e. shorter cells with long tufts of cilia. Through these cells small depressions in the outline of the epithelium are formed. I have further observed on the ventral epithelium a wavy contour produced by a shorter length of a part of the ordinary epithelial cells.

The basement membrane is thin and the muscular wall of the body is, like that of Chromoplana, inconsiderable. This feeble development of the muscularis differs remarkably from the typical conditions of the polyclads, in which group the different layers are very distinct, thick and compact. The museularis of Amyella as well as that of Chromoplana resembles that of the alloeocoelean turbellarians.

Nearly all the pigment of Amyella is subdermal and in this respect it differs from the conditions in Chromoplana.

The rhabdites seem exclusively to be formed in subdermal gland-cells. These subepitbelial cells are scarce on the ventral side, but rather numerous on the dorsal side. In the anterior part of the body they occur in more considerable numbers.

This is the first known example of subdermal rhabdite cells occurring in the polyclads. LANG points out that the exclusive occurrence of the rhabdites in the epithelium is just one of the facts which indicate the primitiveness of the polyclads in comparison with the other turbellarians. It is therefore rather interesting to find that a polyclad genus, and a considerably specialized one, possesses true subdermal 
rhabdites. It may here be remembered that some other features, even if they are not very important, are not typical for the polyclads, such as the small size of the body, the feeble development of the muscularis, and the reduction of the number of ovaries.

I have observed true nematocysts in the parenchyma, but not to any considerable extent. In most cases the capsules still contain their (coiled) spiral threads and are thus intact. They occur also in the lumen of the gut-branches and in the intestinal epithelium, which affords evidence that they really are of foreign origin and introduced with the food. They are infrequent in the external epithelium.

The number of subdermal mucous gland cells is not excessively great.

The pharynx is folded to the same extent as that of Chromoplana. The intestine is also similar to that genus.

\section{Generative organs.}

The testes, which possess well-marked membranae propriae, are always ventral to the gut-branches, numerous, and never large (only $60 \mu$ or less in diameter).

As the sections were stained with Ebrlichs Haematoxylin and Pikro-Fuchsin, the most vivid contrast was obtained between the blue-stained germinative layer and the yellow yolk of the mature oocyte, in which the former layer was imbedded.

The ovaries are remarkably few and also situated ventrally to the digestive system. They occur among the testes, never situated more ventrally than these. When an ovary possesses a ripe oocyte, and never more than one is present at the same time in one ovary, a peculiar aspect is given to the ovary. The germinative zone is placed in a hollow of the ripening oocyte. A section of the ovary shows the oocyte crescent-shaped and thus the ovarial cells of younger stages are to a great extent surrounded by the more or less ripe oocyte (text fig. 6, Plate 2, fig. 2 and 6). The ovary in itself is strictly spherical. The position of the germinative zone in the ovary varies, being dorsal, lateral or ventral. When an ovary contains a fully ripe oocyte the germinative zone is insignificant in comparison with this egg. The small ovarial cells are of about the same size (text fig. 6). The 
SIXTEN BOCK, TWO NEW COTYL. GEN. OF POLYCLADS. 25

cells of the ovary apart from the single larger oocyte lack any traces of yolk-granulæ. Nor is there yet any chromophilous substance which starts the forming of the yolk. Thus the cells contain a homogeneous-looking plasma, i. e. pure protoplasma.

The reduction of the number of ovaries stands in relation to the size of the mature eggs, in this case as well in Chromoplana, Enterogonimus, Laidlawia and Leptoteredra. All

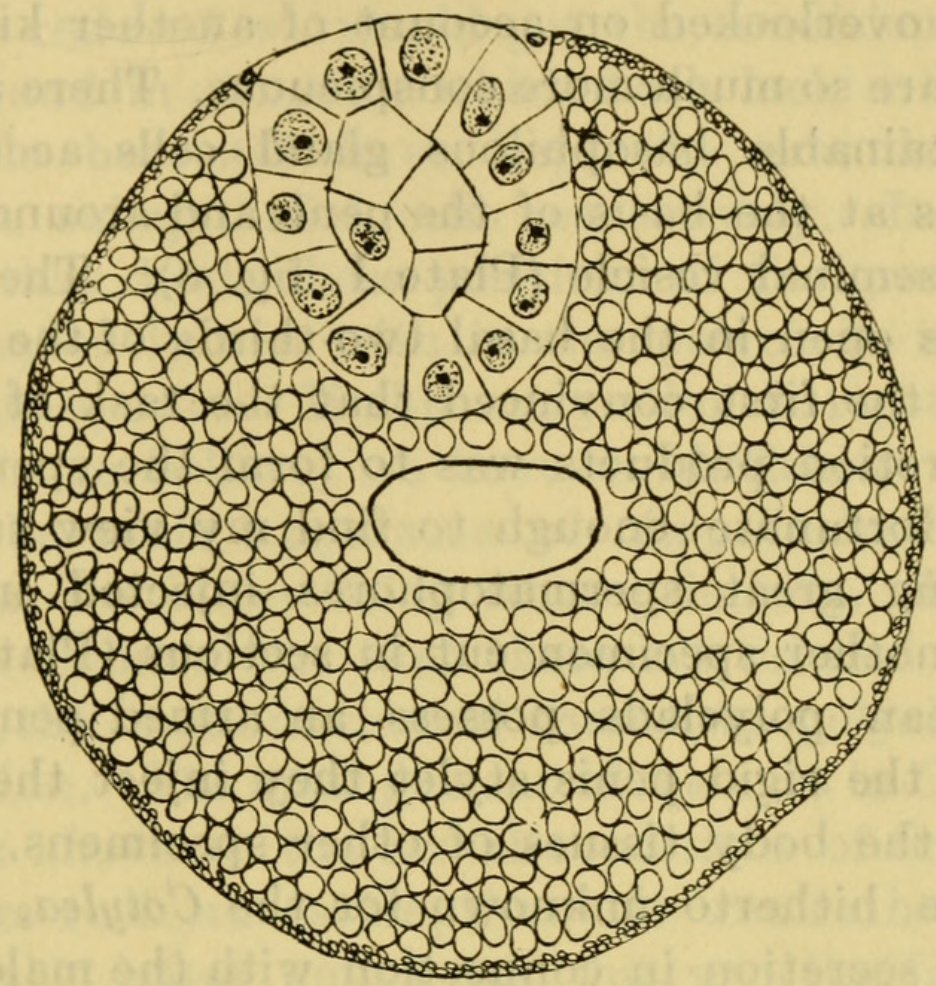

Fig. 6.

Amyella lineata n. g. n. sp. Section of ovary, with germinating zone and the large oocyte with its oval nucleus. Zeiss $1,8 \mathrm{~mm} . \times$ Oc. 1 .

these small-sized animals are not able to deliver a large amount of such gigantic eggs at the same time and thus all these genera have the number of the ovaries reduced.

The whole male copulatory apparatus is directed forward like that of Chromoplana. At first sight the apparatus seems to consist only of a large thin-walled seminal vesicle and an unarmed thick fleshy penis filling up the whole antrum masculinum. (Plate 2, fig. 5). There is no penis fold (= Penisscheide).

The penis is pierced by a nearly straight, rather wide canal running from the seminal vesicle to the tip of the penis. A closer investigation will show the granular gland- 
cells which open in this penis canal without any dilatation of the canal. As the secretion products of these prostatic gland cells are very feebly stainable, their presence is rather hard to detect when using low power lenses of the microscope. Their staining ability agrees fairly well with that of the musculation of the penis. I have had an opportunity to describe similar granular cells emptying their secretion products in the ejaculatory duct of Cryptocelis Ijimai Bock (Bock, 1922). The presence of these granular gland cells is also easily overlooked on account of another kind of gland cells which are so much more conspicuous. There are, namely, intensely stainable basophilous gland cells accumulated in great masses at the basis of the penis and around the frontal end of the seminal vesicle (Plate I, fig. 5). The ductules of these glands open in the basal two-thirds of the penis canal. I was from the first convinced that the task of these basophilous secretion products was to form the spermatophores and I was fortunate enough to find my view supported so far in finding great spermatophores injected in the body tissues of another specimen cut in sections (Plate II, fig. 3). Most cotylean polyclads possess an armed penis and with the help of the rigid penis stylet they inject their masses of sperma in the body tissues of other specimens. Spermatophores were hitherto unknown for the Cotylea, as was also basophilous secretion in connection with the male apparatus. The presence of these spermatophores will explain why the penis of Amyella is unarmed, so large, and provided with such a wide canal. The stout muscular penis can bring about the injection of the sperma in the body tissue by means of these spermatophores. The spermatophore capsules were stained exactly in the same way as the secretion of the lastmentioned glands. Of course there might remain some slight doubts that the observed spermatophores were not to be attributed to Amyella but, so far as I know, no other polyclad species to which they could be attributed lived in the localities for Amyella which I had reason to visit very frequently. It is perhaps superfluous to mention that the spermatozoa were quite typical for a polyclad.

As mentioned above, the granular gland-cells open in the penis canal. According to my opinion a part of that canal corresponds to the prostatic vesicle of other cotylean 
SIXTEN BOCK, TWO NEW COTYL. GEN. OF POLYCLADS. 27

polyclads. I may here refer to the cotylean genus Pericelis, which posesses granular gland-cells in the epithelium of the ductus ejaculatorius without any special vesicle being formed. The description of Chromoplana makes it more easy to homologize this part of the penis canal with the true prostatic vesicle, as in that case, the only known example in the Cotylea, the duct from the vesicula seminalis (the ductus ejaculatorius) opens direct into the prostatic vesicle. If the muscular wall of that vesicle of Chromoplana and its slight lumen were reduced we would get the conditions prevailing in Pericelis and in Amyella, which both lack a distinct prostatic vesicle but still have kept the granular glands as epithelial or subepithelial cells respectively. It may be remembered that both these positions of the granular glandcells are frequently met with in the polyclads, in most cases in the same species. If this suggestion is right, as I have every reason to believe, we have no difficulty to trace the origin of the male apparatus of Amyella back to that of Chromoplana, the latter being more primitive. It ought perhaps to be pointed out that there are no real obstacles in the rest of the organisation of these two polyclads to such an assumption. The arrangement of the eyes in Chromoplana, traced back above to the larval conditions of the Cotyleans, even favours such an assumption. It was rather interesting to obtain the latter genus, as this was the first cotylean with a prostatic vesicle in which the seminal duct opens. I may here mention that another example of such a condition was found by me in a new peculiar cotylean genus Boninia from the Pacific (Bock 1922).

To return to Amyella, the antrum masculinum is situated in the closest proximity to the pharyngeal chamber. The external male porus is not, as might be expected from the anteriorly directed penis, situated in the anterior part of the antrum but is placed farther back, in the closest vicinity to the female porus. The apex of the penis in the position of rest passes beyond the opening of the antrum. Thus the male porus comes to te situated at a farther distance from the mouth than the approach of the male apparatus to the pharynx would indicate. In this respect, but certainly of less significance, we have a more primitive feature than in Chromoplana. It must, however, be pointed out that this 
feature of Chromoplana, certainly indicating a more advanced stage, is not a direct obstacle to my interpretation above, but it may easily be interpreted as a secondarily acquired condition, independent of relationship. It is certainly a fairly general tendency in the Cotylea, where in the Euryleptidean series this approach of the male porus to the mouth culminates in Stylostomum. But in the polyclads there is a considerable variation of the distance between the male porus and the mouth even in closely allied genera. One of the best examples may be taken from the very natural acotylean family Stylochidce, in the scope I have given it (Bock, 1913). In the typical case the sexual pores are very close to one another in the back end of the body (in Stylochus); in Idioplanoides ( $=$ Woodworthia LAIDLAw, 1904) they are close to one another but not removed so extremely near the posterior margin of the body as in certain species of Stylochus; in Cryptophallus and Parastylochus there is a fair distance between the sexual pores, and finally, this distance is considerable in Meixneria. In this family we may trace a backward movement of the genital openings, while in the Euryleptidae a movement in just the opposite direction has taken place.

With regard to the female organs the ovaries are already treated above. No uteri were observed in the specimens of this genus, just as was the case in Chromoplana. That is rather surprising, as the specimen of which the female apparatus is drawn in Plate $I$, fig. 5 possessed eggs nearly ready for deposit, to judge at least from their appearance and large size. It may, however, be pointed out that the nuclei of the large oocytes have not yet entered into division but that stage is never reached by the oocytes of other polyclads while the eggs remain in the ovaries. Therefore one cannot expect to find these oocytes either in such a stage. I am in favour of the assumption that the uteri are never developed in this polyclad rather than that they only appear later on in the individual life. Just the small number of eggs delivered at the same time would render unnecessary an assemblage sac, which the uterus of other polyclads in reality represents. That a reduction of the uteri has taken place in polyclads with a small number of ovaries is also to be gathered from Enterogonimus Hallez, Laidlawia Herzig, 
Stylochoides Hallez and Leptoteredra Hallez, the reduction being more or less advanced.

The female apparatus in the median line is very simple. It opens to the exterior extremely close to the male porus or a very short distance behind it (text fig. 5, Plate 2, fig. 5). Some small variation in this respect may take place as indicated in the figure just referred to in comparison with Plate I, fig. 5, which represents another specimen. The internal part of the vagina, which is placed immediately below the seminal vesicle and above the sucker, is a narrow and short duct compared with the same part of Chromoplana. The shell-chamber is only slightly dilated and has not that characteristic horisontal widening which is so common in the Cotylea. Accordingly it is more tube-like as in the Acotylea, not sac-like as it generally is in the Cotylea. The course of the vagina differs also from what is typical for the Cotylea. The vagina is not sharply bent and has not the distal part running vertically but pursues a direct course obliquely ventrally and anteriorly. The characteristic anterior curve of the vagina of the Acotylea which is more feebly expressed in the Cotylea is totally lacking here.

To the new family, Chromoplanidae, I give this diagnosis:

Small cotylean polyclads with a vivid colour caused by pigment granules. No tentacles. Two clusters of cerebral eyes; marginal eyes only at the frontal end of the body. Pharynx large and much folded, situated in the anterior half of the body. Mouth at the middle of the pharyngeal area. Male apparatus directed forward and situated close to the pharynx. Penis unarmed with or without penis folds. Seminal vesicle opens into the prostatic vesicle (which can be partly reduced). Ovaries few, situated ventrally and producing large ova.

The genus Chromoplana is characterized as follows:

Chromoplanids of oval outline. Cerebral clusters of very few eyes. Male porus in closest proximity to the mouth. Penis with penis folds. Prostatic vesicle large, pear-shaped. An accessory seminal vesicle behind the true vesicula seminalis. Female apparatus of ordinary cotylean type, at a distance behind the male apparatus. Marginal sensorial furrows.

One species from Japan. 
The genus Amyella is given the following diagnosis:

Chromoplanids with elongated body. The clusters of the cerebral eyes elongated. Sexual openings close to each other beneath the end of the pharynx. Penis large without penis folds. Prostatic vesicle reduced to a canal piercing the penis. Female apparatus tube-like and situated below the male apparatus. Rhabdite glands subdermal.

One species from Japan.

\section{Literature.}

Bock, Sixten 1913. Studien über Polycladen. Zool. Bidrag från Uppsala, Bd. 2.

GrafF, L. von 1890. Enantia spinifera, der Repräsentant einer neuen Polycladen-Familie. Mitth. naturw. Ver. f. Steiermark. Jahrg. 1889. Graz 1890. Pag. 1-16, mit 1 Tab.

Hallez, P. 1905. Note préliminaire sur les Polyclades recueillis dans l'Expédition antarctique du François. Bull. Soc. Zool. de France, Année 1905. Paris 1905.

- 1907. Polyclades et Triclades maricoles. Expédition Antarctique française (1903-1905) commandée par le Dr. JeAN Charcot. Juillet 1907. Paris

- - 1913. Polyclades et Triclades maricoles. Deuxième Expédition Antarctique Française (1908-1910) commandée par le Dr. Jean Charcot. Paris 1913.

Heath, H., \& E. A. Mc. Gregor, 1912. New Polyclads from Monterey Bay, California. Proceed. Academy of Natural Sciences of Philadelphia. Vol. LXIV.

Herzig, E. M. 1905. Laidlawia trigonopora n. gen. n. sp. Zoolog. Anz. Bd. XXIX. Leipzig 1905. Pнg. 329-332.

Jacubowa, Lydia. 1906. Polycladen von Neu-Britannien und Neu-Caledonien. Jenaische Ztschr. f. Naturwiss. Bd. XLI. [Neue Folge Bd. 34.] Jena 1906.

- 1909. Les polyclades de la Baie de Sébastopol. St. Pétersburg Mem. Acad. Sciences. Ser. 8. Tom. 24. 1909.

LAIDLA W, F. F. 1902. The Marine Turbellaria, with an Account of the Anatomy of some of the Species. In: The Fauna and Geography of the Maldive and Laccadive Archipelagoes. Vol. I. Part. III. 1902.

LANG, A. 1884. Die Polycladen. Eine Monographie. Fauna und Flora des Golfes von Neapel und der angrenzenden Meeresabschnitte, herausgegeben von der Zool. Station in Neapel. XI. Monographie. Leipzig 1884.

Mreixner, A. 1907. Polycladen von der Somaliküste, nebst einer Revision der Stylochinen. Zeitschrift für wiss. Zoologie. Bd. 88. Leipzig 1907. Pag. 385.

ZAHONY, R. Ritter von, 1907. Turbellarien: Polycladiden. Ergebnisse Hamburger Magalhaensischen Sammelreise. 1892-93. Bd. III. Hamburg $1896-1907$. 
SIXTEN BOCK, TWO NEW COTYL. GEN. OF POLYCLADS. 31

\section{Explanation of Plates I \& II.}

\section{Plate 1.}

Fig. 1. Chromoplana bella n. g. n. sp. $8 \times$.

》2. Amyella lineata n. g. n. sp. $15 \times$.

\3. Chromoplana bella. The ventral side.

"4. Amyella lineata. Section of a young ovary. Zeiss Obj. 1,8 mm. $\times$ Oc. 2.

\5. Amyella lineata. Sagittal section of genital apparatus. Zeiss Obj. $\mathrm{B} \times$ Oc. 4. a. m. antrum masculinum; s. ch. shell chamber; S sucker; v. s. vesicula seminalis. The dark glands are cyanophilous, the other are granular.

\section{Plate 2.}

All the figures, except fig. 4, have their dorsal side turned to the left side of the plate.

Fig. 1. Chromoplana bella. Longitudinal (sagittal) section of the body, to show the marginal sensorial furrow. The gland cells situated ventrally to the furrow are dark. Empty cnidarian capsules can be seen on the dorsal side above.

Fig. 2. Amyella lineata. Sagittal section of the body. An ovary with a large oucyte and the germinating layer inbedded in it. Beneath the dorsal epithelium the (black-looking) pigment is visible.

Fig. 3. Amyella lineata. Sagittal section through the anterior end. The second notch represents the transverse sensorial furrow, above which ganglion cells are visible. To the extreme right is a spermatophore (looking quite black).

Fig. 4. Amyella lineata. Sagittal section through a yonger animal than the one represented in Fig. 2. Ventrally to the gut-branch is a young ovary. The nucleus with a large nucleolus of the single large oocyte is situated more ventrally. This nucleus surpasses in size any of the ovarial cells forming the germinating zone surrounded by the large oocyte. More ventrally the testes are situated. Beneath the dorsal epithelium a fow bunnches of rhabites are visible. d. dorsal, v. ventral side.

Fig. 5. Amyella lineata. Sagittal section through the genital apparatus of a specimen other than that represented in Plate I, Fig. 5. The folded pharynx, the large main gut, the thick black-coloured penis in the middle are clearly visible. The delicate tissue between the antrum masculinum and the pharyngeal chamber has burst in the section. The large black mass to the extreme right is the sperma in the seminal vesicle. Beneath the male apparatus is the female apparatus and ventrally of it the sucker, S. Close to the left (near Fig. 4) is the mouth, m.

Fig. 6. Amyella lineata. The photo represents the half of an ovary with germinating zone and the nucleus of the large oocyte.

Tryckt den 8 april 1922.

Uppsala 1922. Almqvist \& Wiksells Boktryckeri-A.-B. 


\section{$2 \mathrm{BHL}$ Biodiversity Heritage Library}

1922. "Two new Cotylean genera of Polyclads from Japan and remarks on some other Cotyleans." Arkiv för zoologi 14, 1-31.

https://doi.org/10.5962/bhl.part.7726.

View This Item Online: https://www.biodiversitylibrary.org/item/30164

DOI: https://doi.org/10.5962/bhl.part.7726

Permalink: https://www.biodiversitylibrary.org/partpdf/7726

\section{Holding Institution}

MBLWHOI Library

\section{Sponsored by}

MBLWHOI Library

\section{Copyright \& Reuse}

Copyright Status: NOT_IN_COPYRIGHT

This document was created from content at the Biodiversity Heritage Library, the world's largest open access digital library for biodiversity literature and archives. Visit BHL at https://www.biodiversitylibrary.org. 